\title{
Coprophilous fungi from dung of the Greater One-Horned Rhino in Kaziranga National Park, India and its implication to paleoherbivory and paleoecology
}

\author{
Sadhan K. Basumatary ${ }^{\mathrm{a}}$, H. Gregory McDonald ${ }^{\mathrm{b}}$ \\ ${ }^{a}$ Birbal Sahni Institute of Palaeosciences, 53 University Road, Lucknow, Uttar Pradesh, 226007, India \\ ${ }^{\mathrm{b}}$ Bureau of Land Management, Utah State Office, 440 West 200 South, Salt Lake City, Utah 84101, USA \\ (RECEIVED October 21, 2016; AcCEPTED March 24, 2017)
}

\begin{abstract}
Fungal spores, especially those of coprophilous fungi, are present in dung middens of Rhinoceros unicornis (greater one-horned rhinoceros) in both forest and grassland areas of the Kaziranga National Park, India. The presence of coprophilous fungi on rhino dung, chiefly Sporormiella, Saccobolus, Ascodesmis, Cercophora, and Sordaria, is documented for the first time. The Sporormiella-Ascodesmis-Saccobolus assemblage is abundant and characterizes the rhino dung in forest and grassland areas. The presence of coprophilous fungi spores allows for an examination of the relationship between rhinoceros ecology and the flora and other fauna in the region. The overall dataset is useful in interpreting the present and past distribution of rhino and other associated animals based on the relative abundance of different types of coprophilous fungi spores and their relationship to paleoherbivory and paleoecology in India and adjoining areas.
\end{abstract}

Keywords: Ecology; Endangered species; Fungal spectra; Grassland; Megaherbivores; Dung midden; Rhinoceros unicornis

\section{INTRODUCTION}

During the late Pleistocene most of the megafauna, both herbivores and carnivores, became extinct on all the major continents (Martin, 1967, 1984; Barnosky et al., 2004). Previous studies on the cause of this megafaunal extinction in different parts of the globe have tended to focus on two primary causes, climatic and anthropogenic (Martin, 1973; MacPhee, 1999; Miller et al., 1999; Grayson and Meltzer, 2002). The current rate of population reduction and potential extinction of herbivores and carnivores in the wild is a major global ecological issue. Currently about $60 \%$ of the large herbivorous animals are now threatened with possible extinction (Ripple et al., 2015). Southeast Asia contains the world's highest number of threatened mammals (Schipper et al., 2008), with regional faunas experiencing ongoing range reductions and extinctions driven by human activities (Brook et al., 2014). In India, a preliminary report on the status of the mega-herbivores, including the greater onehorned rhinoceros (Rhinoceros unicornis, Linnaeus, 1758;

* Corresponding author at: Birbal Sahni Institute of Palaeosciences, 53 University Road, Lucknow, Uttar Pradesh, 226007, India. E-mail address: sbasumatary2005@yahoo.co.in (S.K. Basumatary). also known as the Indian rhino) describes the high probability of their local extinction (Karanth et al., 2016).

The study of the dung of individual species is an important source of information on food preferences, habitat utilized, and ecology in general. Studies of fungal remains preserved in peat and lake sediments can complement palynodata in interpreting the paleovegetation and past climate in the region (van Geel, 1978, 1986, 2001; van Geel et al., 1981, 1989; Gill et al., 2009; Cugny et al., 2010; Feeser and O'Connell, 2010; Kramer et al., 2010; Montoya et al., 2010; Mudie et al., 2010) and in archaeological sites (van Geel et al., 2003; Zong et al., 2007; Gauthier et al., 2010; McAndrews and Turton, 2010; Rattighieri et al., 2013; Revelles et al., 2016). Studies have been carried out on coprophilous fungi in surface and sedimentary soil profiles to document or infer the former presence, and subsequent decline of, herbivorous animals in a region (Davis, 1987; Burney et al., 2003; Barnosky et al., 2004; Robinson et al., 2005; Raper and Bush, 2009). Feranec et al. (2011) noted the need for more studies to better understand Sporormiella as a proxy and to identify whether particular taxa are only present on the dung of specific herbivores. Here we document the presence, types, and abundance of the coprophilous fungi and associated spores present in the dung of Rhinoceros unicornis in Kaziranga National Park, India. 
The generated dataset can serve as a critical proxy to document the former existence of rhinoceroses in a region through samples collected from the surface and sediment/soil sediments that preserve coprophilous fungi.

Rhinoceros unicornis is one of the largest living megaherbivores in the world and is now a critically endangered species (Poudyal et al., 2009). One of the unique behaviors of rhinoceroses, including Rhinoceros unicornis is to consistently use the same location for their daily excretion and multiple individuals may deposit dung at this site or midden over several years. The historical distribution of Rhinoceros unicornis includes habitats in northern and central India, and Pakistan (Rao, 1947; Banerjee and Chakraborty, 1973; Mathpal, 1978), but Rhinoceros unicornis is absent in these regions today. The current distribution of Rhinoceros unicornis, now restricted to a few areas in the Assam region of India and Nepal, is considerably smaller than the historical distribution of the species.

\section{STUDY SITE, FLORA, AND FAUNA}

Kaziranga National Park is an ideal place for the investigation of Rhinoceros unicornis in its natural habitat and to understand the ecology of the species. The park has the highest population of Rhinoceros unicornis in the world and the population has been increasing at a positive rate from 366 individuals in 1966 to 2048 individuals in 2009 (Medhi and Saha, 2014). In 2015 the rhino population was 2401 (Sharma, 2016). The park lies between $26^{\circ} 32^{\prime}$ and $26^{\circ} 47^{\prime} \mathrm{N}$, and $93^{\circ} 07^{\prime} \mathrm{E}$ to $93^{\circ} 38^{\prime} \mathrm{E}$, at an elevation between $45-90 \mathrm{~m}$ above sea level (Fig. 1). The vegetation is mainly tropical, semievergreen, deciduous, savannah, and grassland (Champion and Seth, 1968). A list of flora in the park is provided in Table 1.

The Kaziranga National Park has rich and diverse vertebrate fauna. Among the herbivores, along with the Rhinoceros unicornis (one-horned rhino; Fig. 2a), the other

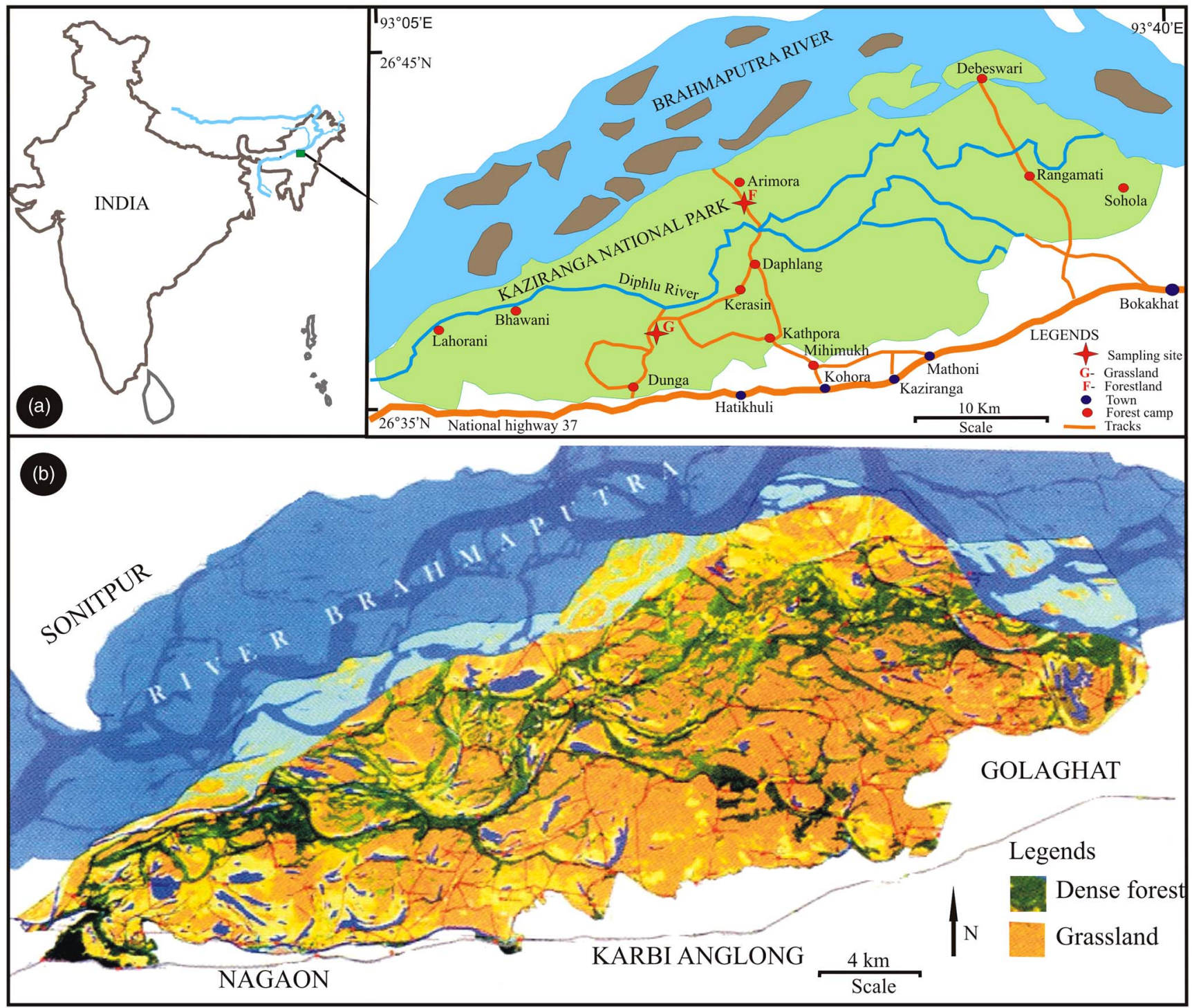

Figure 1. (color online) (a) Location of the study area. (b) Land cover map of the Kaziranga National Park, India (modified after Das et al., 2014) 
Table 1. Plant taxa present in the Kaziranga National Park, India.

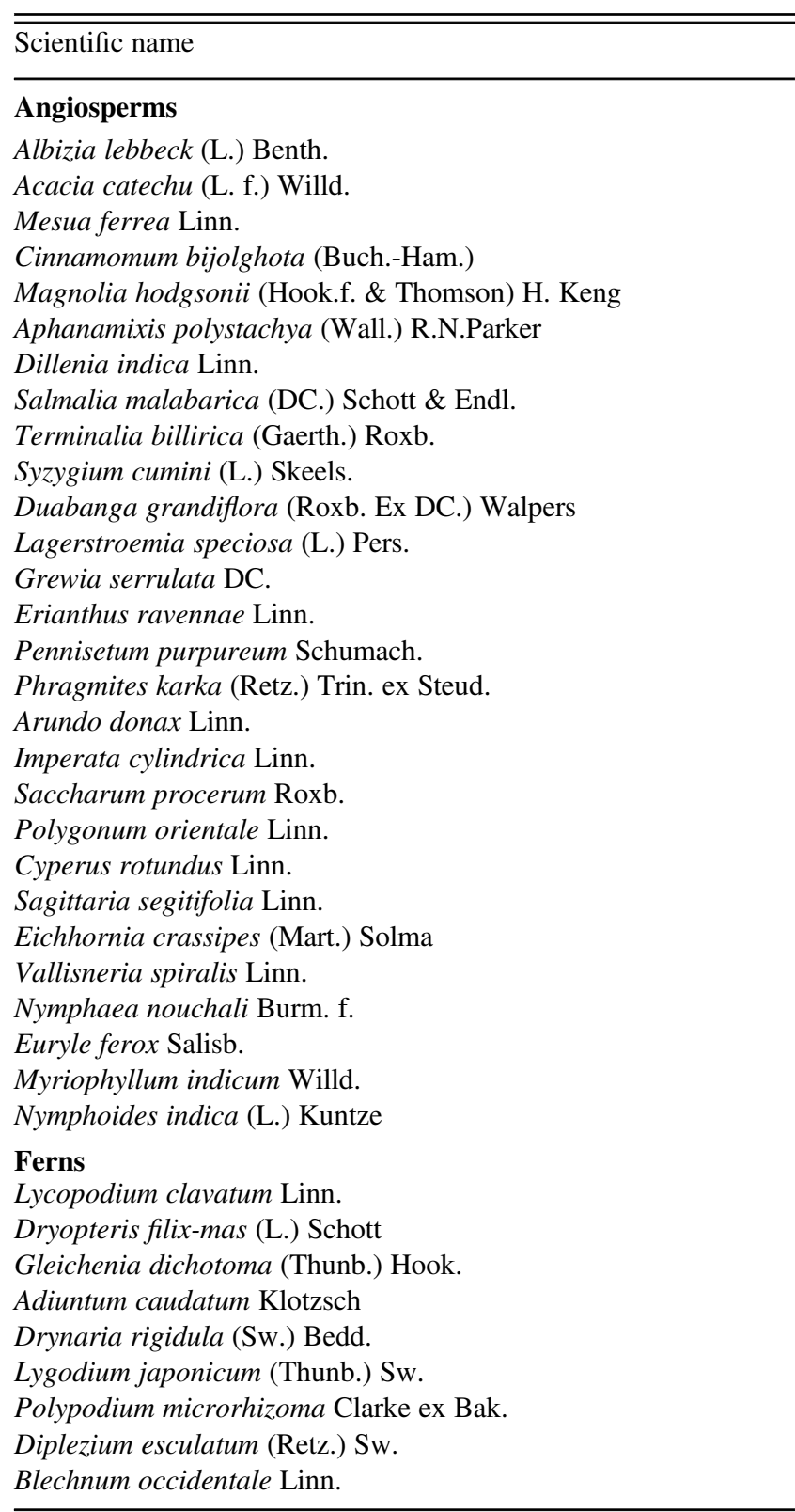

common mammalian herbivores are Bubalus arnee, Elephas maximus, Rusa unicolor, and Rucervus duvaucelii.

\section{CLIMATE AND SOIL}

The climate of the region is controlled by the southwest and northeast monsoons:, it is hot and humid during the summer, and cold and dry during winter. The maximum temperature ranges from a minimum of $4^{\circ} \mathrm{C}$ during winter up to $37^{\circ} \mathrm{C}$ in summer. The relative humidity is very high and ranges from 75 to $86 \%$. The annual rainfall ranges from 1800 to $2600 \mathrm{~mm}$, and annual flooding is very common in the Kaziranga National Park. The soil composition varies from site to site and includes sandy loam soil in forests, sandy soil in grassland, and clayey soil in the swamp and water bodies (Das et al., 2014).

\section{MATERIAL AND METHOD}

A total of 10 Rhinoceros unicornis dung samples (G1-G10), each consisting of $\sim 100 \mathrm{~g}$, were collected from the Rhinoceros unicornis dung midden close to the road within the grassland area in the western part of the Kaziranga National Park. Samples were collected from the center to periphery of the dung midden. Another 10 samples (F1-F10) of similar size were collected from a dung midden in the forested area close to the road in the central part of the park. The accumulations of rhino dung in the sites sampled are the result of consistent use by multiple individuals of Rhinoceros unicornis for at least several years. The middens were about $27.9-32.5 \mathrm{~m}^{2}$ in area and approximately $0.6 \mathrm{~m}$ in thickness. The dung samples were collected from above the ground level and below the surface of the dung to avoid contamination by the surface soil and atmospheric particles (Fig. 2b-d).

The dung samples were processed using the standard acetolysis method (Erdtman, 1943). Samples were successively treated with $10 \%$ aqueous potassium hydroxide $(\mathrm{KOH})$ solution to deflocculate the sediments, $40 \%$ hydrofluoric acid (HF) to dissolve silica, and acetolysis (9:1 anhydrous acetic acid to concentrated sulphuric acid, $\left.\left[\mathrm{H}_{2} \mathrm{SO}_{4}\right]\right)$. Thereafter, the samples were treated twice with glacial acetic acid (GAA), and washed 3 or 4 times with distilled water. The samples were then transferred to a $50 \%$ glycerol solution with a few drops of phenol to protect against microbial decomposition. Excluding pollen grain and fern spores, 421 to 470 fungal spores were counted from each sample to produce the fungal spore spectra. Observation of the fungal spores and microphotographs was performed using an Olympus BX-61 microscope with DP-25 digital camera under 40x magnification (Fig. 3). The identified fungal spores were categorized as coprophilous and noncoprophilous fungi. We consulted the literature as well as published papers to aid in identification of fungal spores (van Geel, 2003; Cugny et al., 2010; Gross, 2011; Mungai et al., 2011; Basumatary et al., 2014; van Asperen et al., 2016).

\section{RESULTS}

\section{Fungal spore spectra}

The fungal spectra in Rhinoceros unicornis dung samples from the forested and grassland area are listed in Tables 2 and 3. In the forested area, 10 dung samples (F1-F10) collected from the rhino dung midden located in the forested area of Kaziranga National Park (Fig. 1) were characterized by the predominance of coprophilous fungi (70.7\%) over noncoprophilous fungi (29.3\%). Among coprophilous fungi, Sporormiella (18.4\%) was the most common, followed by Ascodesmis (17.4\%) and Saccobolus (17.2\%). Cercophora, 

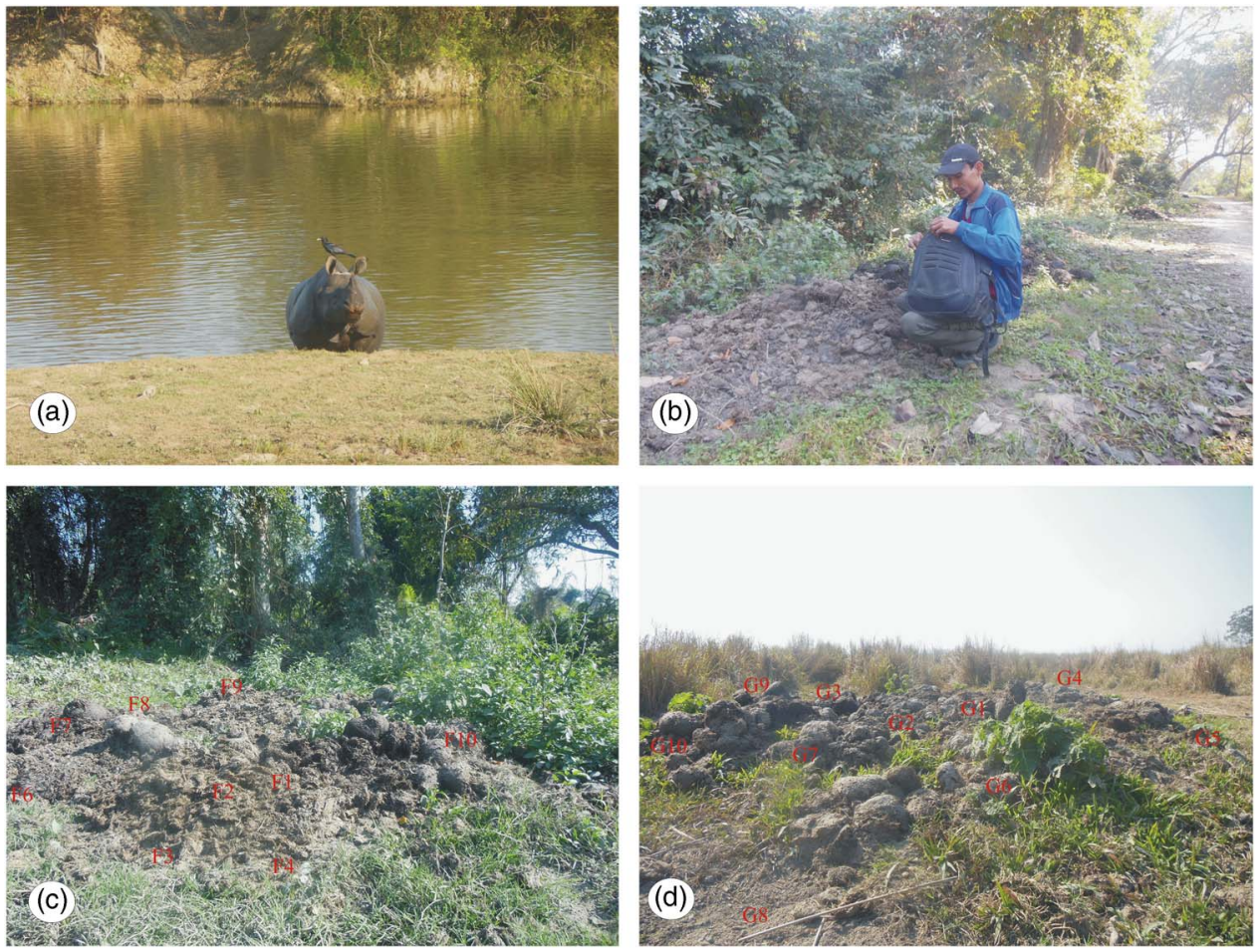

Figure 2. (a) Rhinoceros unicornis in its natural habit in Kaziranga National Park (b) A view of a field photograph during midden dung observation by Basumatary. (c) Sampling locations (red numbers) on Rhinoceros unicornis midden in forest area. (d) Sampling locations (red numbers) on Rhinoceros unicornis midden in grassland area. (For interpretations of the references to color in this figure legend, the reader is referred to the web version of this article.)

Gelasinospora, Podospora, and Sordaria had values of $2.3 \%$ to $6.4 \%$. The non-coprophilous fungi, chiefly the Microthyriaceae, Glomus, Tetraploa, Meliola, and Helminthosporium, were recorded within the range of $1.5 \%$ to $4.6 \%$ (Fig. 4).

The 10 dung samples (G1-G10) collected in the grassland area from the Rhinoceros unicornis dung midden located in the forested area of Kaziranga National Park (Fig. 1) were also characterized by the dominance of coprophilous fungi (77.9\%) over non-coprophilous fungi $(22.1 \%)$. Among coprophilous fungi, the Sporormiella (20.3\%), Ascodesmis (18.6\%), and Saccobolus (18.3\%) are the most common taxa, while Cercophora, Coniochaete, and Sordaria varied from 2.3 to $7.7 \%$. The non-coprophilous fungi are chiefly Helminthosporium, Cookeina, Tetraploa, and Alternaria, which ranged from 1.0 to $4.9 \%$ (Fig. 4).

\section{DISCUSSION}

A total of 18 fungal spore types were identified in Rhinoceros unicornis dung midden samples collected both from grassland and forest area samples in Kaziranga National Park. The coprophilous fungi were predominant over non-coprophilous fungi in grassland and forested areas. The study reveals that Sporormiella, Saccobolus, and Ascodesmis were frequent and dominant in all of the studied samples. Baker et al. (2013) listed spore types associated with megaherbivore dung based on empirical evidence and, while they included Sporormiella, neither Saccobolus nor Ascodesmis were included in their study. Richardson (2001) documented that some taxa of cophrophilous fungi may have a preference for specific dung types and further research is needed to confirm whether these later two taxa are specific to Rhinoceros unicornis dung. However, other coprophilous fungi such as Cercophora, Sordaria, Podospora, and Gelasinospora listed by Baker et al. (2013) were also consistently present in the assemblage from the Rhinoceros unicornis dung. It is, however, the presence of Sporormiella in the surface and lake soil sediments that currently is considered to serve as a powerful proxy for the present and past existence of herbivores and birds as a part of the paleoecological reconstruction of a region (van Geel et al., 2003; Graf and Chmura, 2006; Raper and Bush, 2009; Parker and Williams, 2012; Etienne et al., 2013). The presence of the spores of Sporormiella greater than $2 \%$ in a pollen sample is considered a strong indication of the presence of megafauna in the region (Davis, 1987; Raczka et al., 2016). Feranec et al. (2011) noted that more taphonomic study is needed on how spores of coprophilous fungi enter the stratigraphic record and to identify the preservation potential of Sporormiella spores in different habitat and sediment types. They cite Nyberg and Persson (2002), who show that fungal diversity in moose (Alcesalces) dung was promoted in pine forest but suppressed in spruce forest. Our study partially addresses the issue of differential spore preservation. There does not appear to be any 

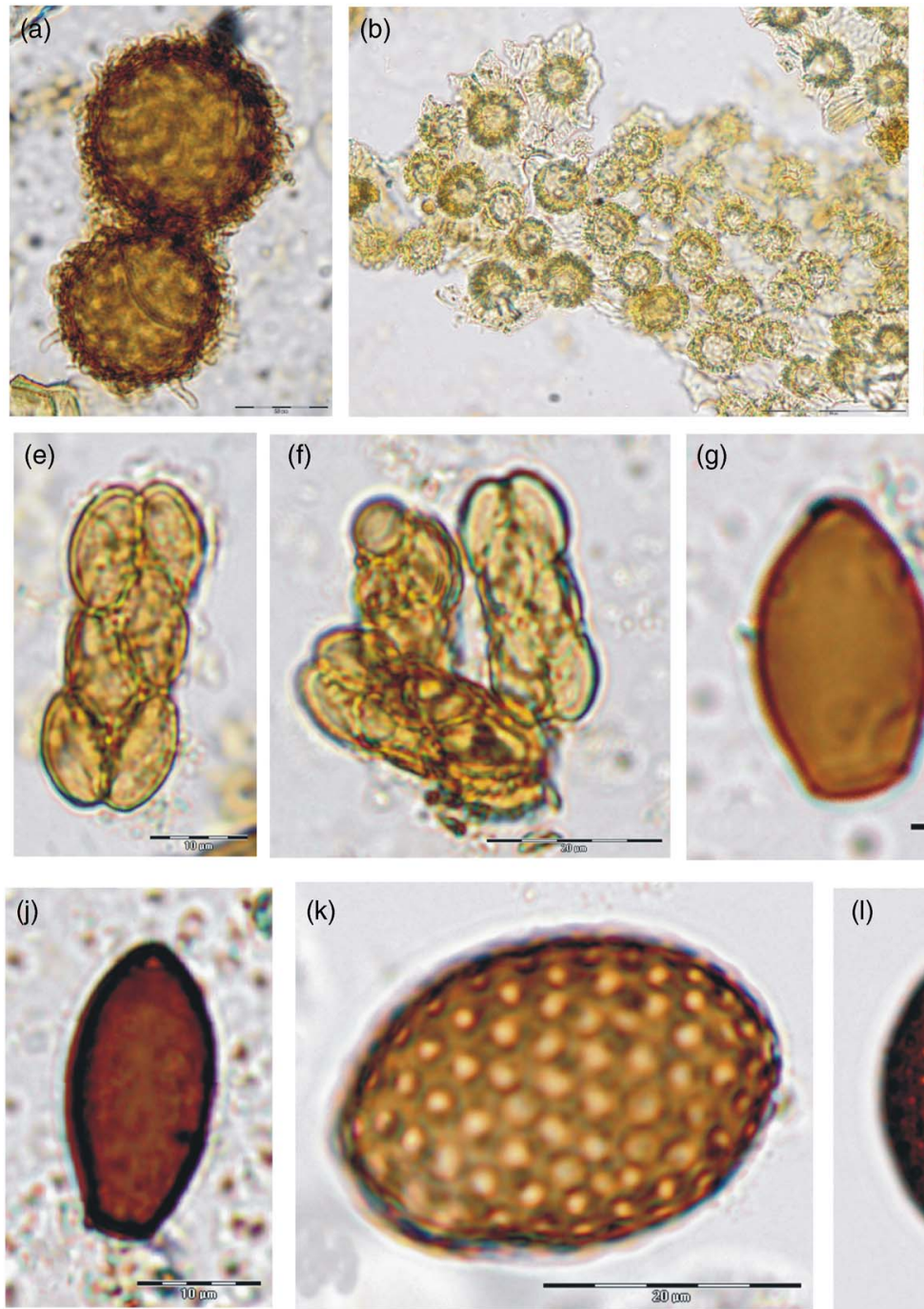

(k)
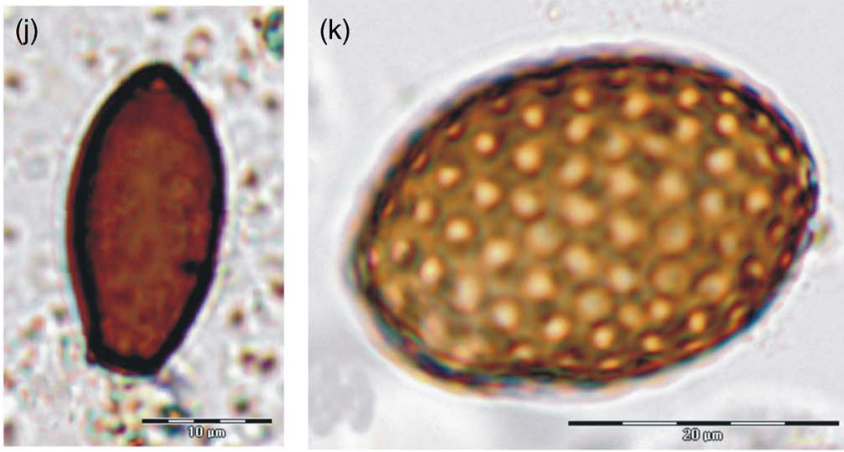

(I)
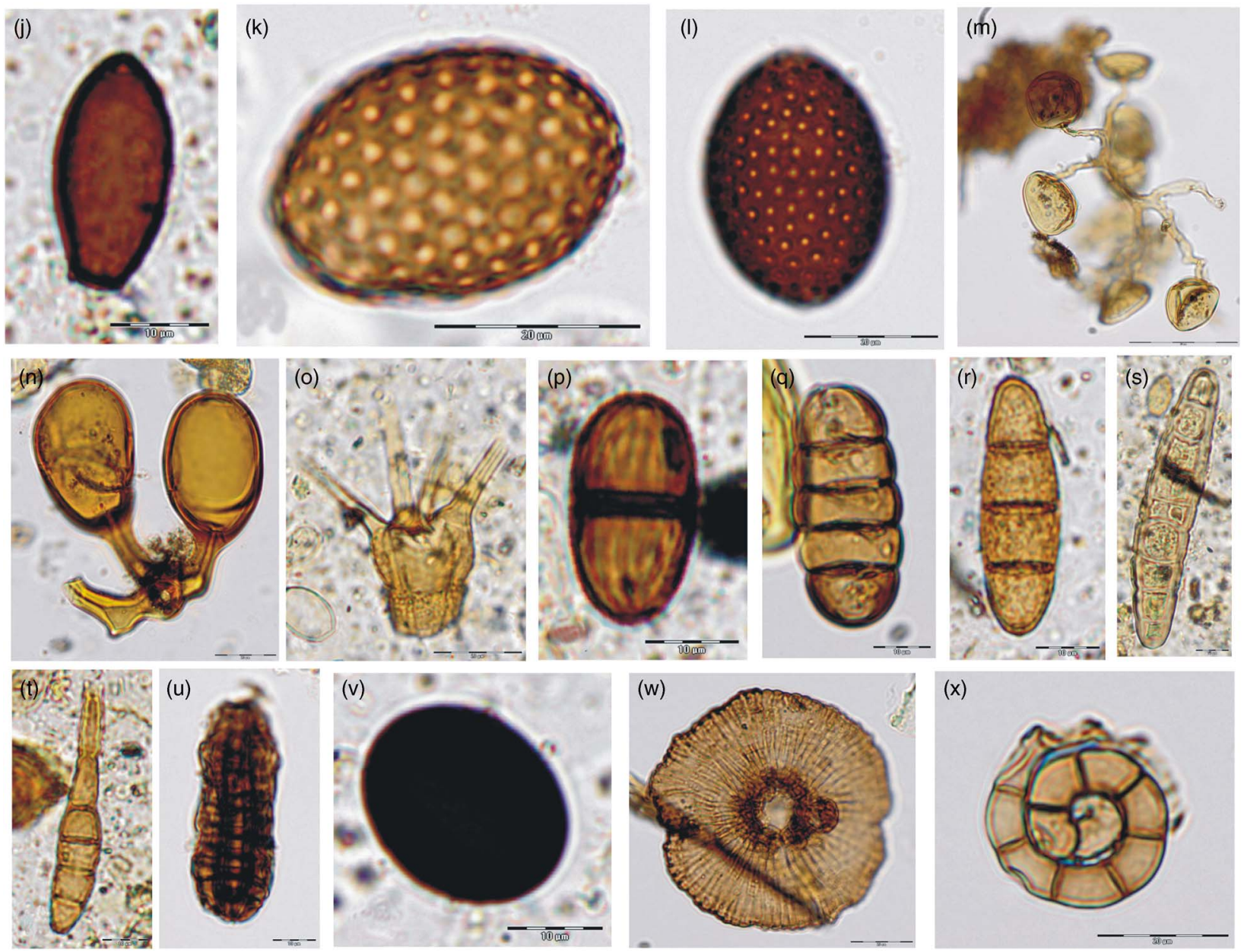

$(\mathrm{x})$

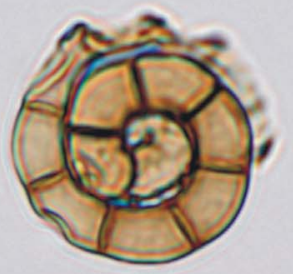

-

Figure 3. (color online) Fungal remains recovered from Rhinoceros unicornis dung midden samples in Kaziranga National Park, India. (a and b) Clumping of Ascodesmis. (c) Clumping of Sporormiella. (d) Group of Sporormiella. (e and f) Clumping of Saccolobus. (g and h) Cercophora. (i) Podospora. (j) Sordaria. (k and 1) Gelasinospora. (m and n) Glomus with Hyphae. (o) Tetraploa. (p) Cookeina. (q and r) Meliola. (s) Helminthosporium. (t) Alternaria. (u) Dictyosporium. (v) Nigrospora. (w) Microthyriaceae. (x) Helicoon. 
Table 2. The fungal spore frequency data recovered from the rhino dung midden from the forest area. Numbers are given as percentages.

\begin{tabular}{|c|c|c|c|c|c|c|c|c|c|c|}
\hline Sample number & $\mathrm{F} 1$ & $\mathrm{~F} 2$ & $\mathrm{~F} 3$ & $\mathrm{~F} 4$ & F5 & F6 & F7 & F8 & F9 & $\mathrm{F} 10$ \\
\hline \multicolumn{11}{|c|}{ Name of fungal taxa } \\
\hline Sporormiella & 17.7 & 19.3 & 17.3 & 16.6 & 18.5 & 19.4 & 19.7 & 20.2 & 16.8 & 18.1 \\
\hline Saccobolus & 18.2 & 17.1 & 17.3 & 17.9 & 17.2 & 17.6 & 15.7 & 17.7 & 16.8 & 16.8 \\
\hline Ascodesmis & 17.0 & 15.9 & 17.9 & 18.4 & 18.8 & 17.6 & 17.7 & 17.2 & 16.5 & 17.6 \\
\hline Cercophora & 4.6 & 4.9 & 4.8 & 3.6 & 3.4 & 5.2 & 3.8 & 5.1 & 6.4 & 3.5 \\
\hline Sordaria & 5.1 & 3.4 & 3.3 & 3.1 & 2.4 & 4.4 & 3.3 & 2.5 & 3.6 & 4.3 \\
\hline Gelasinospora & 3.0 & 4.9 & 4.1 & 2.8 & 3.4 & 2.3 & 3.0 & 3.3 & 2.8 & 3.3 \\
\hline Podospora & 3.0 & 3.4 & 3.8 & 4.6 & 3.7 & 2.1 & 3.5 & 3.0 & 2.3 & 3.0 \\
\hline Coniochaete & 2.3 & 3.2 & 2.8 & 3.6 & 3.4 & 2.3 & 3.0 & 2.8 & 3.1 & 3.8 \\
\hline Nigrospora & 2.0 & 2.2 & 1.5 & 1.8 & 1.3 & 1.8 & 1.5 & 1.8 & 2.1 & 1.5 \\
\hline Glomus & 3.8 & 3.9 & 3.1 & 3.6 & 3.4 & 4.4 & 4.8 & 5.6 & 4.4 & 4.5 \\
\hline Tetraploa & 4.6 & 4.6 & 5.4 & 4.6 & 4.2 & 3.4 & 4.5 & 4.3 & 4.6 & 4.0 \\
\hline Helminthosporium & 2.5 & 2.2 & 3.1 & 3.6 & 3.2 & 2.6 & 3.5 & 2.3 & 2.3 & 2.5 \\
\hline Alternaria & 1.5 & 2.0 & 1.5 & 1.8 & 2.6 & 2.8 & 2.0 & 3.0 & 3.9 & 3.3 \\
\hline Cookeina & 3.8 & 3.4 & 4.6 & 4.3 & 3.4 & 3.1 & 3.5 & 2.5 & 2.3 & 2.0 \\
\hline Microthyriaceae & 3.5 & 2.9 & 2.8 & 2.6 & 3.2 & 3.6 & 3.3 & 2.5 & 4.1 & 3.5 \\
\hline Meliola & 3.0 & 2.4 & 2.0 & 2.8 & 3.7 & 2.6 & 3.0 & 2.5 & 2.8 & 3.3 \\
\hline Dictyosporium & 2.0 & 2.2 & 2.6 & 2.0 & 2.4 & 2.6 & 2.0 & 2.3 & 2.3 & 2.0 \\
\hline Helicoon & 2.3 & 2.0 & 2.0 & 2.3 & 1.6 & 2.3 & 2.0 & 1.5 & 2.8 & 3.0 \\
\hline
\end{tabular}

difference in the relative abundance of fungal spores in the dung of Rhinoceros unicornis recovered from two distinct habitats, forest and grassland. Similarly, the presence of Sporormiella in Pleistocene samples have been used as a direct indicator for the presence of extinct megaherbivores based on the study of mammoth (Mammuthus columbi) dung recovered in Bechan Cave (southern Utah) (Davis, 1987). The clumping of coprophilous fungi spores, especially Sporormiella, Saccobolus, and Ascodesmis, in the Rhinoceros unicornis dung midden samples was very common and indicative of their local origin. In coprophilous fungi, especially
Sporormiella, the spores have low dispersal capacity and produce localized concentrations rather than being dispersed across the region and generally are transported less than $100 \mathrm{~m}$ from the source area (Davis and Shafer, 2006; Raper and Bush, 2009; Parker and Williams, 2012; Gill et al., 2013). The fungal spores are therefore strictly local in origin and become preserved close to the source where sporulation occurred (van Geel and Aptroot, 2006). In our study of Rhinoceros unicornis dung midden samples, the Sporormiella-Saccobolus-Ascodesmis assemblage was a strong indicator of rhinoceros, as indicated by their regular presence and high abundance in all the samples.

Table 3. The fungal spore frequency data recovered from the rhino dung midden from the grassland.

\begin{tabular}{|c|c|c|c|c|c|c|c|c|c|c|}
\hline Sample number & G1 & G2 & G3 & G4 & G5 & G6 & G7 & G8 & G9 & G10 \\
\hline \multicolumn{11}{|c|}{ Name of fungal taxa } \\
\hline Sporormiella & 21.3 & 20.9 & 18.9 & 18.3 & 20.5 & 20.1 & 21.6 & 21.4 & 19.9 & 20.0 \\
\hline Saccobolus & 19.5 & 18.6 & 18.4 & 17.0 & 19.7 & 19.3 & 17.8 & 18.4 & 19.1 & 18.3 \\
\hline Ascodesmis & 18.2 & 15.8 & 18.6 & 17.3 & 16.8 & 20.1 & 19.8 & 18.2 & 18.6 & 19.5 \\
\hline Cercophora & 5.2 & 5.8 & 5.5 & 5.0 & 5.6 & 6.0 & 4.6 & 5.8 & 7.7 & 4.9 \\
\hline Sordaria & 3.9 & 4.7 & 4.3 & 3.7 & 2.7 & 4.5 & 3.8 & 2.9 & 4.3 & 4.7 \\
\hline Gelasinospora & 3.6 & 5.8 & 5.0 & 4.2 & 4.5 & 3.0 & 3.6 & 3.9 & 3.2 & 3.5 \\
\hline Podospora & 3.9 & 4.4 & 4.3 & 5.2 & 4.3 & 2.8 & 4.1 & 3.2 & 2.9 & 3.5 \\
\hline Coniochaete & 2.6 & 3.3 & 3.3 & 4.5 & 4.0 & 2.5 & 2.3 & 2.9 & 3.5 & 4.2 \\
\hline Nigrospora & 1.3 & 1.4 & 1.0 & 1.6 & 1.1 & 1.5 & 1.0 & 1.0 & 1.6 & 2.2 \\
\hline Glomus & 3.4 & 3.5 & 2.5 & 3.4 & 2.9 & 4.0 & 4.6 & 4.9 & 3.7 & 4.2 \\
\hline Tetraploa & 3.6 & 2.8 & 3.8 & 4.5 & 3.5 & 2.5 & 3.8 & 3.2 & 2.9 & 3.5 \\
\hline Helminthosporium & 3.9 & 3.0 & 4.5 & 5.2 & 4.3 & 3.5 & 4.6 & 2.7 & 2.7 & 2.7 \\
\hline Alternaria & 1.3 & 1.4 & 1.8 & 2.4 & 1.3 & 2.0 & 1.5 & 1.7 & 1.3 & 2.2 \\
\hline Cookeina & 2.6 & 2.1 & 2.0 & 1.8 & 2.1 & 1.5 & 1.0 & 1.5 & 1.3 & 1.0 \\
\hline Microthyriaceae & 1.8 & 1.4 & 1.3 & 2.1 & 1.6 & 1.8 & 2.3 & 2.4 & 2.1 & 1.5 \\
\hline Meliola & 1.6 & 2.1 & 1.0 & 1.6 & 2.1 & 2.5 & 1.3 & 1.9 & 1.9 & 1.2 \\
\hline Dictyosporium & 1.3 & 1.4 & 1.8 & 1.0 & 1.3 & 1.5 & 1.0 & 1.7 & 1.3 & 1.7 \\
\hline Helicoon & 1.0 & 1.6 & 2.0 & 1.3 & 1.6 & 1.0 & 1.3 & 2.4 & 1.9 & 1.2 \\
\hline
\end{tabular}




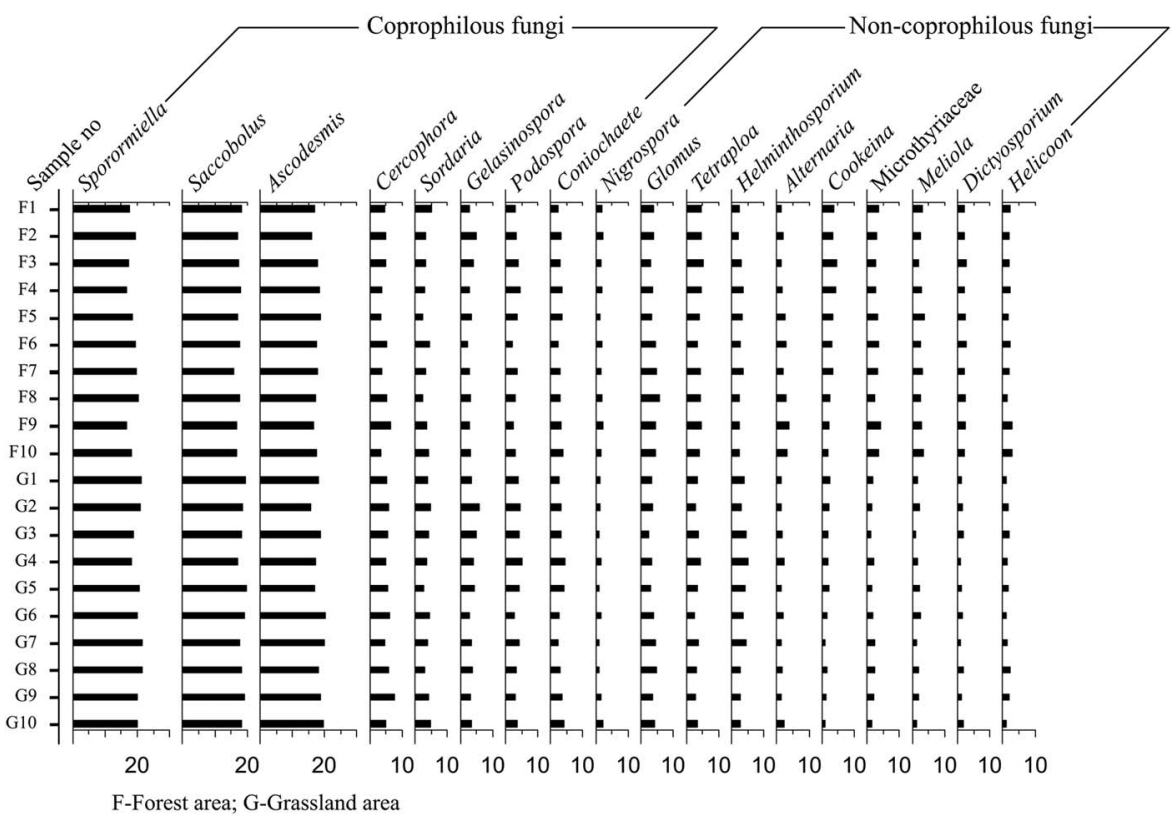

Figure 4. Comparison of fungal spectra of Rhinoceros unicornis dung midden samples collected from the forest and grassland area in Kaziranga National Park, India.

The high amount of coprophilous fungi along with other associated fungal spores is indicative of the warm and humid condition in the region because water availability is the important factor for the germination and sporulation of Sporormiella (Austin, 1958; Ingold and Marshall, 1962; Kuthubutheen and Webster, 1986a, 1986b). The presence of Cercophora in the assemblage has also been observed in dung and is also an indicator of woodland and grassland environments (Blackford and Innes, 2006; Graf and Chmura, 2006). The Sporormiella-Saccobolus-Ascodesmis assemblage is considered specifically characteristic for Rhinoceros unicornis dung based on their abundance in the dung midden samples. In our dataset, it is observed that, in addition to the Sporormiella, the other two taxa, Saccobolus, and Ascodesmis, were most frequently present with values $>15 \%$. The Sporormiella-Saccobolus-Ascodesmis assemblage is characteristic of rhino dung, as indicated by their consistent high frequency (16-21\%) and clustering spores in all the examined samples. In contrast, non-coprophilous fungi such as Tetraploa, Cookeina, Meliola, and Dictyosporium have a relatively low presence in the assemblage and the consistency of their presence in the dung needs more investigation. The high body temperature $\left(\sim 37^{\circ} \mathrm{C}\right)$ and acidic environment in the gut of herbivorous animals may be the main reason that non-coprophilous fungal spores are destroyed if they are consumed during feeding.

The continuous and comparatively high presence of Microthyriaceae (epiphyllous fungi) and Helicoon in the dung samples collected from the forest area was very significant (1-2\%). The presence of such fungi in the assemblage is indicative of the dense forest vegetation under warm and humid conditions in response to the high rainfall in the region (Cookson, 1947; Selkirk, 1975; Reddy et al., 1982;
Johnson and Sutton, 2000; Limaye et al., 2007; Hofmann, 2010; Medeanic and Silva, 2010). The comparatively high value of Helminthosporium (3.7\%) in the assemblage of grassland dung samples is of interest, as it is a common pathogen in grasses. The presence of Tetraploa and Glomus in the assemblage of both area samples suggests water-logged conditions with rich plant diversity that might be incorporated through the ingestion of plants, water, and soil, as these fungi are commonly found on leaf bases, roots, and stems of Poaceae and Cyperaceae (Ellis, 1971; Tanaka et al., 2009).

\section{CONCLUSIONS}

This study demonstrates that the Sporormiella-SaccobolusAscodesmis assemblage is distinctive and characteristic of Rhinoceros unicornis dung. The documentation of the coprophilous fungi present in surface soil sediments in the region can complement the data provided by the analysis of the Rhinoceros unicornis dung midden samples in Kaziranga National Park and its vicinity. The resulting fungal dataset on Rhinoceros unicornis dung can provide a baseline that can help us to document the past presence of Rhinoceros unicornis based on the study of sedimentary soil profile in Kaziranga National Park and neighboring regions. The dataset also can serve as a powerful tool to determine the past distribution and ecology of Rhinoceros unicornis in India and neighboring areas when other evidence such as bones are not available. Combined with a study of the pollen and fungal spores preserved in the dung of other herbivores animals in the region, this approach provides a way of recognizing the distribution of other animals that are found in the same habitat as Rhinoceros unicornis prior to their extirpation. Further research is needed that includes surface 
and sedimentary soil samples beyond the perimeter of the Rhinoceros unicornis dung midden to determine if they preserve a different or similar fungal spore assemblage than that seen in the Rhinoceros unicornis dung midden samples.

\section{ACKNOWLEDGMENTS}

We thank Prof. Sunil Bajpai, Director, Birbal Sahni Institute of Palaeosciences (BSIP), Lucknow, India for laboratory facilities to carry out this research. First author is very much thankful to Department of Science and Technology, New Delhi for funding (DST No: SB/EMEQ-225/2014 (SERB) the research work. First author acknowledge the forest department, Goverment of Assam for necessary help during field observation. Authors are also thankful to Mr. Sandeep K. Kohri, Project Assistant, for assistance in the samples maceration and technical help during the preparation of the manuscript.

\section{REFERENCES}

Baker, A.G., Bhagwat, S.A., Willis, K.J., 2013. Do dung fungal spores make a good proxy for past distributions of large herbivores. Quaternary Science Reviews 62, 21-31.

Barnosky, A.D., Koch, P.L., Feranec, R.S., Wing, S.L., Shabel, A.B., 2004. Assessing the causes of Late Pleistocene extinctions on the continents. Science 306, 70-75.

Basumatary, S.K., Bera, S.K., Sangma, S.N., Marak, G., 2014. Modern pollen deposition in relation to vegetation and climate of Balpakram valley, Meghalaya, northeast India: Implications for Indo- Burma palaeoecological contexts. Quaternary International 325, 30-40.

Blackford, J.J., Innes, J.B., 2006. Linking current environments and processes to fungal spore assemblages: Surface NPM data from woodland environments. Review of Palaeobotany and Palynology 141, 179-187.

Brook, S.M., Dudley, N., Mahood, S.P., Polet, G., Williams, A.C., Duckworth, J.W., Van Ngoc, T., Long, B., 2014. Lessons learned from the loss of a flagship: The extinction of the Javan rhinoceros Rhinoceros sondaicus annamiticus from Vietnam. Biological Conservation 174, 21-29.

Burney, D.A., Robinson, G.S., Burney, L.P., 2003. Sporormiella and the late Holocene extinctions in Madagascar. Proceedings of the National Academy of Sciences of the United States of America 100, 10800-10805.

Champion, H.G., Seth, S.K., 1968. A revised survey of the forest type of India. Govt. of India Press, Delhi, India.

Cookson, S.D., 1947. Fossil fungi from Tertiary deposits in the southern Hemisphere; part I. Proceeding of the Linnean Society of New South Wales 72, 207-214.

Cugny, C., Mazier, F., Galop, D., 2010. Modern and fossil nonpollen palynomorphs from the Basque mountains (western Pyrenees, France): the use of coprophilous fungi to reconstruct pastoral activity. Vegetation History and Archaeobotany 19, 391-408.

Das, D.J., Kumar, V., Bora, H.R., Verma, P.K., Gogoi, P., Gogoi, R., Vasu, N.K., 2014. Land cover mapping and dynamics of Kaziranga national park, Assam, India. Indian Forester 140, 11-17.

Davis, O.K., 1987. Spores of the dung fungus Sporormiella: Increased abundance in historic sediments and before Pleistocene megafaunal extinction. Quaternary Research 28, 290-294.
Davis, O.K., Shafer, D.S., 2006. Sporormiella fungal spores, a palynological means of detecting herbivore density. Palaeogeography, Palaeoclimatology, Palaeoecology 237, 40-50.

Dinerstein, E., 2003. The Return Of The Unicorns: The Natural History and Conservation of the Greater One-Horned Rhinoceros. Columbia University Press, New York.

Erdtman, G., 1943. An Introduction to Pollen Analysis. Chronica Botanica Company, Waltham, MA, USA.

Etienne, D., Wilhelm, B., Sabatier, P., Reyss, J.L., Arnaud, F., 2013. Influence of sample location and livestock numbers on Sporormiella concentrations and accumulation rates in surface sediments of Lake Allos, French Alps. Journal of Paleolimnology 49, 117-127.

Feranec, R.S., Miller, N.G., Lothrop, J.C., Graham, R.W., 2011. The Sporormiella proxy and end-Pleistocene megafaunal extinction: a perspective. Quaternary International 245, 333-338.

Gill, J.L., Williams, J.W., Jackson, S.T., Lininger, K.B., Robinson, G.S., 2009. Pleistocene megafaunal collapse, novel plant communities, and enhanced fire regimes in North America. Science 326, 1100-1103.

Gill, J.L., McLauchlan, K.K., Skibbe, A.M., Goring, S., Zirbel, C.R., Williams, J.W., 2013. Linking abundances of the dung fungus Sporormiella to the density of bison: implications for assessing grazing by megaherbivores in palaeorecords. Journal of Ecology 101, 1125-1136.

Graf, M., Chmura, G.L., 2006. Development of modern analogues for natural, mowed, and grazed grasslands using pollen assemblages and coprophilous fungi. Review of Paleobotany and Palynology 141, 139-149.

Grayson, D.K., Meltzer, D.J., 2002. Clovis hunting and large mammal extinction: a critical review of the evidence. Journal of World Prehistory 16, 313-359.

Kuthubutheen, A.J., Webster, J., 1986a. Water availability and the coprophilous fungi succession. Transactions of the British Mycological Society 86, 63-76.

Kuthubutheen, A.J., Webster, J., 1986b. Effects of water availability on germination, growth and sporulation of coprophilous fungi. Transactions of the British Mycological Society 86, 77-91.

Limaye, R.D., Kumaran, K.P.N., Nair, K.M., Padmalal, D., 2007. Non-pollen palynomorphs as potential palaeoenvironmental indicators in the late Quaternary sediments of the west coast of India. Current Science 92, 1370-1382.

McAndrews, J.H., Turton, C.L., 2010. Fungal spores record Iroquoian and Canadian agriculture in 2nd millennium A.D. sediment of Crawford Lake, Ontario, Canada. Vegetation History and Archaeobotany 19, 495-501.

Martin, P.S., 1967. Prehistoric Overkill. In: Martin, P.S., Wright, H.E. (Eds.), Pleistocene Extinctions: The Search for a Cause. Yale University Press, New Haven, pp. 75-120.

Martin, P.S., 1984. Prehistoric Overkill: The Global Model. In: Martin, P.S., Klein, R.G. (Eds.), Quaternary Extinctions: A Prehistoric Revolution. University of Arizona Press, Tucson, pp. 354-403.

Martin, P.S., 1973. The Discovery of America. Science 179, 969-974.

Mathpal, Y., 1978. Prehistoric Rock Paintings of Bhimbetka, Central India. PhD dissertation, University of Poona, Pune, India.

Medeanic, S., Silva, M.B., 2010. Indicative value of non-pollen palynomorphs (NPPs) and palynofacies for palaeoreconstructions: Holocene Peat, Brazil. International Journal of Coal Geology 84, 248-257.

Medhi, A., Saha, A.K., 2014. Land cover change and rhino habitat mapping of Kaziranga National Park, Assam. In: Singh, M., Singh, R.B., Hassan, M.I. (Eds.), Climate Change and Biodiversity: Proceedings of IGU Rohtak Conference, Vol. 1, 
Advances in Geographical and Environmental Sciences. Springer, Tokyo, Japan, pp. 125-138. http://dx.doi.org/10.1007/ 978-4-431-54838-6_10.

Miller, G.H., Magee, J.W., Johnson, B.J., Fogel, M.L., Spooner, N.A., Mcculloch, M.T., Ayliffe, L.K., 1999. Pleistocene extinction of Genyornis newtoni: human impact on Australian megafauna. Science 283, 205-208.

Mungai, P., Hyde, K.D., Cai, L., Njogu, J., Chukeatirote, K., 2011. Coprophilous ascomycetes of northern Thailand. Current Research in Environmental \& Applied Mycology 1, 135-159.

Nyberg, A., Persson, I.L., 2002. Habitat differences of coprophilous fungi on moose dung. Mycological Research 106, 1360-1366.

Poudyal, M.K., Rothley, K., Knowler, D., 2009. Ecological and economic analysis of poaching of the greater one-horned rhinoceros (Rhinoceros unicornis) in Nepal. Ecological Applications 19, 1693-1707.

Raczka, M.F., Bush, M.B., Folcik, A.M., McMichael, C.H., 2016. Sporormiella as a tool for detecting the presence of large herbivores in the Neotropics. Biota Neotropica 16, e20150090, 2016. http://dx.doi.org/10.1590/1676-0611-BN-2015-0090.

Rao, H.S., 1947. History of our knowledge of the Indian fauna through the ages. Journal of Bombay Natural Historical Society 54, 251-280.

Raper, D., Bush, M., 2009. A test of Sporormiella representation as a predictor of megaherbivore presence and abundance. Quaternary Research 71, 490-496.

Rattighieri, E., Rinaldi, R., Mercuri, A.M., Bowes, K., 2013. Land use from seasonal archaeological sites: the archaeobotanical evidence of small Roman farmhouses in Cinigiano, south-eastern Tuscany-Central Italy. Annals of Botany 3, 207-215.

Revelles, J., Burjachs, F., van Geel, B., 2016. Pollen and non-pollen palynomorphs from the Early Neolithic settlement of La Draga (Girona, Spain). Review of Paleobotany and Palynology 225, 1-20.

Richardson, M.I., 2001. Diversity and occurrence of coprophilous fungi. Mycological Research 105, 387-402.

Ripple, W.J., Newsome, T.M., Wolf, C., Dirzo, R., Everatt, K.T., Galetti, M., Hayward, M.W., Kerley, G.I., Levi, T., Lindsey, P.A. Macdonald, D.W. 2015. Collapse of the world's largest herbivores. Science Advances 1(4), p.e1400103.

Robinson, G.S., Pigott Burney, L., Burney, D.A., 2005. Landscape paleoecology and megafaunal extinction in southeastern New York State. Ecological Monographs 75, 295-315.
Schipper, J., Chanson, J.S., Chiozza, F., Cox, N.A., Hoffmann, M., Vineet, K., Lamoreux, J., et al., 2008. The status of the world's land and marine mammals: diversity, threat, and knowledge. Science 322, 225-230.

Sharma, S., 2016. DNA indexing to curb rhino poaching in Assam and UP. The Times of India, December 7, 8.

Tanaka, K., Hirayama, K., Yonezawa, H., Hatakeyama, S., Harada, Y., Sano, T., Shirouzu, T., Hosoya, T., 2009. Molecular taxonomy of bambusicolous fungi: Tetraplosphaeriaceae, a new pleosporalean family with Tetraploalike anamorphs. Studies in Mycology 64, 175-209.

van Asperen, E.N., Kirby, J.R., Hunt, C.O., 2016. The effect of preparation methods on dung fungal spores: Implications for recognition of megafaunal populations. Review of Palaeobotany and Palynology 229, 1-8.

van Geel, B., 1978. A palaeoecological study of Holocene peat bog sections in Germany and the Netherlands, based on the analysis of pollen, spores and macro-and microscopic remains of fungi, algae, cormophytes and animals. Review of Palaeobotany and Palynology 25, 1-120.

van Geel, B., 1986. Application of fungal and algal remains and microfossils in palynological analyses. In Berglund, B.E. (ed.), Handbook of Holocene Palaeoecology and Palaeohydrology. Wiley, chichester. pp. 497-505.

van Geel, B., 2001. Non-pollen palynomorphs. In Smol, J.P., Birks, H.J.P., Last W.M., editors, Tracking environmental change using lake sediments. Vol. 3, Terrestrial, algal and siliceous indicators. Dordrecht: Kluwer Academic Press. pp. 99-119.

van Geel, B., Aptroot, A., 2006. Fossil ascomycetes in Quaternary deposits. Nova Hedwig 82, 313-329.

van Geel, B., Bohncke, S., Dee, H., 1981. A palaeoecological study of an upper late glacial and Holocene sequence from "De Borchert", The Netherlands. Review of Palaeobotany and Palynology 31, 367-448.

van Geel, B., Buurman, J., Brinkkemper, O., Schelvis, J., Aptroot, A., van Reenen, G., Hakbijl, T., 2003. Environmental reconstruction of a Roman Period settlement site in Uitgeest (The Netherlands), with special reference to coprophilous fungi. Journal of Archaeological Science 30, 873-883.

Zong, Y., Chen, Z., Innes, J.B., Chen, C., Wang, Z., Wang, H., 2007. Fire and flood management of coastal swamp enabled first rice paddy cultivation in east China. Nature 449, 459-462. 